\title{
MAURÍCIO TRAGTENBERG: 10 ANOS DE ENCANTAMENTO*
}

\author{
ROBERTO HELOANI ${ }^{* *}$
}

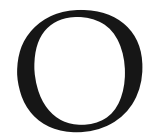

livro Maurício Tragtenberg: 10 anos de encantamento, organizado por Antonio José Romera Valverde, teve sua origem no evento homônimo que ocorreu na PUC-SP, em novembro de 2008. O acontecimento contou não só com a participação de professores e pesquisadores ligados à academia, como também com a presença de ex-alunos, artistas, sindicalistas, além de representantes dos mais variados setores civis da sociedade. Como se explica tão vasta e diversificada confluência? Será devido à genialidade e vastíssima cultura deste grande intelectual e mestre? A sua capacidade de sintetizar e reinterpretar ideias que vão de Weber a Bakhunin, tangenciando e, às vezes, passando por Marx? Decerto, tal fato é de suma relevância, mas não explica tudo. O carisma, o humanismo e o profundo sentimento de solidariedade e compaixão de Maurício Tragtenberg por certo também foram decisivos.

A riqueza do material, organizado neste livro que tenho a honra de resenhar, está relacionada ao tipo de abordagem crítica que Tragtenberg fazia de temas complexos da política, da economia, do mundo do trabalho, do sindicalismo e da defesa de minorias. A crítica independente e a liberdade de pensamento são marcas características desses escritos, um traço muito raro nos dias de hoje.

Os escritos expressam a capacidade que Maurício - como gostava de ser chamado - tinha de transpor seu conhecimento, de forma inteligível e provocativa, para públicos diferenciados. Se Maurício Tragtenberg debruçava-se sobre complexas e alentadas obras clássicas, muitas delas escritas em idiomas estrangeiros, entre eles o alemão, o inglês, o italiano e o francês, com a mesma dedicação e respeito escrevia para o povo e pelo povo em jornais dirigidos à grande massa de trabalhadores, como o Notícias Populares, no qual escreveu por muitos anos uma coluna intitulada "No

\footnotetext{
* Resenha do livro Tragtenberg: 10 anos de encantamento, organizado por Antonio José Romera Valverde (São Paulo: Educ; Fapesp, 2011).

** Faculdade de Educação e Instituto de Filosofia e Ciências Humanas da Universidade Estadual de Campinas (Unicamp). Campinas (SP) - Brasil.

Contato com o autor: <rheloani@gmail.com>
} 
Batente", ou mesmo os artigos enviados a veículos como a Folha de S. Paulo e o Jornal da Tarde, voltados a um público mais intelectualizado. Isso dá uma ideia exata do que estamos querendo dizer.

No entanto, devo destacar aqui que Tragtenberg, com sua grande erudição e o amor aos livros, tinha um profundo respeito à inteligência e à capacidade de crítica dos trabalhadores. Naquele contexto, muitos trabalhadores foram movidos a pensar e a refletir criticamente sobre a exploração do trabalho, a política, a economia e a organização sindical. Ao comunicar-se de forma clara com todos os públicos e ao fazer sua opção pela defesa da causa dos trabalhadores, das minorias e dos desfavorecidos, o professor, sem ser professoral, ia se distanciando da recorrente "pedantocracia universitária" e do "salto alto da vida acadêmica".

Ao mesmo tempo - como já dissemos -, Maurício Tragtenberg colaborou com o jornal Folha de S. Paulo, direcionado a outro tipo de leitor, fazendo história com artigos em que divertidamente colocava Weber e Maquiavel, redivivos, respondendo às suas perguntas, como repórter, no que concerne à realidade do Brasil.

Também como colaborador do O São Paulo e da Folha de S. Paulo (FSP), este grande mestre soube demonstrar que o compromisso com a ética deve estar acima de interesses pessoais ou de questões raciais. Apesar de ascendência judaica, sempre reconheceu a necessidade da criação de um Estado palestino: “[...] Da mesma maneira que defendemos o direito de Israel subsistir como Estado, defendemos o direito dos palestinos construírem seu Estado [...]" (O São Paulo, 19 jul. 1982). Ou ainda: "[...] O fato é que sob o nazismo houve o holocausto judaico, isso não justifica haver holocausto de libaneses, drussos, palestinos. O terrorismo israelita no Líbano, com bombas de bilha, de fragmentação, de fósforo, de nada contribui para manter a tradição humanística judaica" (FSP, 21 set. 1982).

É esta figura humana de importância ímpar o centro de reflexão dessa bela obra. Como menciona Antonio Valverde, o livro compõe-se de quatorze capítulos. Treze de análises de aspectos focais da obra deste sociólogo e um depoimento. Logo de início aparece o capítulo "A obra de Maurício Tragtenberg - in memoriam", do professor da Universidade Estadual de Maringá, Antonio Ozaí da Silva, que realça o compromisso deste intelectual que tratava de temas históricos sociológicos, políticos e educacionais "sempre com o compromisso militante e uma perspectiva política crítica à sociedade capitalista e às concepções autoritárias sobre o socialismo". É uma análise da obra de Maurício que nos lembra da forte influência do autor em tantos intelectuais, professores e militantes e deságua na "reafirmação de uma concepção de socialismo libertário".

Doris Accioly e Silva constitui o capítulo "Polifonia e unidade na obra-trajeto de Maurício Tragtenberg". Neste instigante texto, a autora propõe uma releitura da 
obra deste mestre, considerando-se a categoria "afinidades eletivas". Ademais, nos lembra que "A obra de Maurício Tragtenberg espelha alguns dos traços que Ítalo Calvino (1994) definiu como inerentes aos clássicos: a virtude de ser sempre atual e permeável a novas interpretações, podendo ser localizada na genealogia de outros clássicos [...]", e também dá destaque para a profunda coerência de pensamento e ação desse profícuo escritor.

No capítulo seguinte, José Henrique de Faria, no texto intitulado “Burocracia, poder e ideologia", nos ensina qual era a tese central do grande mestre no que concerne à Teoria Geral da Administração (TGA): esta é uma ideologia! Isto faz com que esta TGA seja "uma teoria dominante".

Em seguida, Ana Paula Paes de Paula assina um texto cujo título já diz uma verdade em si: "A magia de Maurício Tragtenberg". Assim, a autora esclarece ao leitor qual a posição de um dos melhores tradutores de Weber no que concerne à burocracia: é como pensador libertário que Tragtenberg procura analisar Weber: a crítica da burocracia que faz se baseando em Weber está ligada ao projeto emancipatório anarquista no qual aposta. Lembra-nos que, além de ser um árduo defensor da autogestão, na figura das organizações horizontais, também segue a tendência anarquista no que concerne ao desenvolvimento de iniciativas de natureza educacional, discutidas por Proudhon, Robin e Ferrer.

Por sua vez, Lucia Bruno, no texto "O político e o econômico na obra de Maurício Tragtenberg", demonstra como o referido autor nunca se esqueceu da relação entre a esfera do político e a do econômico. Mais que isso, lembra-nos que a ideia de que são os próprios trabalhadores autonomamente organizados que devem conduzir suas lutas nega a ideia de "vanguarda" sempre combatida por Maurício, que terá a coragem de criticar o bolchevismo, mormente na sua vertente estalinista.

Com sinceridade e honestidade intelectual, Maria Ester de Freitas resgata aspectos da obra e vida de Maurício no capítulo "Tragtenberg e a questão ideológica da Teoria Geral da Administração". Ela afirma que o seu ex-professor na Fundação Getúlio Vargas (FGV/SP) era um docente cuidadoso com os estudantes: dava aulas maravilhosas, não faltava, nem atrasava e, não raro, passava do horário ou continuava aula no corredor com seus discípulos. Era um orientador prestimoso, mesmo quando não era o docente-orientador oficial. Contudo desabafa: "Foi um privilégio e uma honra ter vivido uma época em que podíamos conviver com professores desse porte. A mim parece que vivemos uma onda obscurantista na profissão e na academia, senão pela proibição das ideias diferentes, pela própria definição na base de perfis profissionais aventureiros e mercenários, cujo compromisso é tão somente relacionado com a produtividade a qualquer preço". 
Em seguida, Afrânio Mendes Catani dá início ao seu capítulo com o título: "Walter Rathenau analisado por Maurício Tragtenberg". Conta-nos a sua história como aluno de Tragtenberg e depois como colega na FGV/SP. Ademais, faz considerações interessantes e pouco conhecidas a respeito de um dos mais importantes empresários alemães que, além de ensaísta social, também era importante filósofo, político e economista em sua época (1867-1922). Maurício demonstrava grande interesse por essa figura ambígua e procurava estudá-la em uma pesquisa na FGV/SP. Este é o foco deste capítulo fascinante.

Em "Travessia", Antonio Jose Romera Valverde defende a tese de que Maurício Tragtenberg "adentrou estruturas diversificadas de pensamentos e de poros da microfísica do poder para construir uma visão política pontual, aprofundada e sobejamente sintética dos conflitos explícitos e latentes do mundo contemporâneo e, particularmente, do Brasil".

Evaldo Vieira, em seu capítulo, faz o papel de pescador: "pesca" trechos significativos em algumas obras de Maurício Tragtenberg que permitem ao leitor fazer suas próprias reflexões. Assuntos atuais, tais como vestibular, repetência diploma, mercado, educação política, entre outros. Não é sem razão que o seu capítulo assim é denominado: "Maurício Tragtenberg: assim vale a pena".

Paulo-Edgar Almeida Resende se conduz por belas memórias e por passagens eruditas no capítulo que bem expressa a coragem do protagonista dessa obra: "Maurício Tragtenberg: ousou saber, ousou dizer". Resende conta, às vezes em detalhes, a convivência com Maurício, na PUC/SP, dez anos depois.

“Maurício Tragtenberg é um parresiasta contemporâneo". É assim que Edson Passetti refere-se ao mestre. No capítulo intitulado "Um parresiasta no socialismo libertário", o autor explica que a parrésia, na antiga democracia ateniense, era uma atitude de homens livres diante da verdade dos governantes. Era a marca de homens que expressavam suas ideias com franqueza, sem medo das consequências, mesmo diante de superiores hierárquicos. O parresiasta era incisivo e, portanto, às vezes, incômodo. Qualquer semelhança não é mera coincidência.

O texto "Um convite: pensar é resistir", assinado por Flávia Schilling e Cintya Ribeiro, nos instiga a pensar: "educar é basicamente introduzir um sujeito numa determinada ordem de discurso?" As autoras problematizam no que concerne à educação, liberdade e formação e, brilhantemente, recorrem a um pensador que nunca foi estranho ao mestre Maurício Tragtenberg: Michel Foucault.

Ainda, Gustavo Gutierrez, em seu texto "Maurício Tragtenberg como um autor complexo", faz alusão àquilo que considera como categorias eleitas por Tragtenberg como capitais, ou seja, burocracia e controle; público, privado e gestão; e, 
logicamente, marxismo heterodoxo. Assim Gutierrez faz verdadeira varredura epistêmica de um autor que enxergava no construto "heterodoxo" a opção por uma liberdade crítica.

Fechando esta bela obra, Ediógenes Aragão dos Santos nos brinda com um comovente e vívido depoimento. Esta, agora docente da Unicamp, relata que conheceu Maurício Tragtenberg em 1961, em um ginásio estadual, no qual assistia, como ouvinte, aulas de História. Sua admiração foi crescendo por "um intelectual erudito, libertário, solidário com as lutas dos trabalhadores" e acrescenta que não foi por mero acaso que se tornou, como ele, professora de História, formada pela Universidade de São Paulo (USP) em plena ditadura militar, colando grau sozinha, sem a sua turma.

Depois de resenhar tão importante obra, o que posso dizer?

Só me resta acrescentar que a melhor homenagem que posso prestar ao Maurício Tragtenberg - que conheci no mestrado, na FGV/SP, quando tínhamos saborosas conversas - é divulgar o seu pensamento e honrar o seu lugar. Para mim, ter resenhado um texto tão belo e tão justo, historicamente falando, é motivo de alegria, apreensão e orgulho concomitantemente. Espero poder corresponder - nem que seja um pouco -, em minha carreira acadêmica, à imagem de um mestre que, para mim, foi mais do que isso: tornou-se um verdadeiro pai intelectual.

Digo isso, pois, em 1994, quando essa maravilhosa pessoa aposentou-se da Unicamp e da FGV/SP, eu, mediante concurso público, vim a ocupar a vaga outrora pertencente a este grande intelectual e educador. Não sei se mereço tal honra e se tenho competência para essa "démarche". Contudo, espero não tê-lo decepcionado muito. 